\title{
The Russian Federation and the Kyoto Protocol
}

\author{
Wybe Th. Douma ${ }^{1}$ \\ Daria Ratsiborinskaya ${ }^{2}$
}

\section{Introduction}

The Russian Federation played a key role in enabling the Kyoto Protocol (KP) to enter into force. Although the country could benefit a lot from the Protocol itself, it ratified only after having secured enough additional political incentives from abroad, notably from the European Union. This strenuous process will first be touched upon. Next, the quantitative obligations arising from the KP for Russia will be discussed, and the potential advantages for Russia of some of the Kyoto mechanisms. After that, the general modalities of actually implementating the KP in Russia and the specific legislation with regard to Joint Implementation (JI) adopted at the end of May 2007 will be turned to. Whether the latter legislation will enable a timely start of JI projects in Russia will be the focus point of the last-but-one part of this chapter. In the final part, some concluding remarks are presented, notably on the prospects of Russia committing itself to a meaningful post-2012 regime.

\section{From signing to ratification}

On 16 February 2007 it was two years since the coming into force of the Kyoto protocol to the UN Framework Convention on Climate Change (UNFCCC). Adopted on 11 December 1997, the Protocol was the first international agreement with quantitative obligations for some of its parties to limit and reduce emissions of greenhouse gases by amounts averaging 5.2 percent by 2008-2012. By June 2007, 173 countries are party to the Protocol, including one regional organization, the European Community.

The fact that the Kyoto Protocol could enter into force depended on the Russian Federation, in the end. The reason for this was that Article 25 of the Protocol made its entry into force dependent on ratification by not less than 55 Parties to the UNFCCC, incorporating Annex I Parties accounting in total for at least 55 per cent of the total carbon dioxide emissions for 1990 of these Annex I Parties. As the USA (responsible for $36.1 \%$ of emissions by Annex I countries) decided not to ratify, crossing the threshold depended on Russia, which represented $17.4 \%$ of the Annex I countries' emissions. ${ }^{3}$ At first, this did not seem to be a problem. In 2001, Russia and the EC anounced that they would work together with a view to early ratification and entry into force of the Kyoto Protocol. ${ }^{4}$ The EC approved the Protocol on 31 May 2002, but Russia needed more time. At the Johannesburg World Summit on Sustainable Development in September 2002, Russia's then Prime-Minister Kashyanov did state that 'ratification will occur in the very near future.' At the same venue, Deputy Minister

\footnotetext{
${ }^{1}$ Ph.D., Head Department for European Law at the T.M.C. Asser Institute.

${ }^{2}$ LL.M., Associate researcher T.M.C. Asser Institute and MGIMO.

${ }^{3}$ Note that in 2003, the USA was the world's largest emitter of CO2, emitting $22 \%$ of the total emissions; the 13 EU Euro-zone countries together accounted for 10\%; China 16\%; Russia 6\% and India 5\%. The per capita emissions of CO2 in the USA were 19.9 metric tons; in China 3.2; in Russia 10.3 and in the EU Euro-zone countries 8.2 (World Bank, 2007 Little Green Data Book, covering emission data for the year 2003). China is expected to surpass the USA and become the world's largest emitter of CO2 either in 2007 or in 2008, according to the International Energy Agency (BBC News 24 April 2007).

${ }^{4}$ Brussels EU-Russia Summit of 3 October 2001, Joint Statement, accessed at http://www.delrus.cec.eu.int/en/p_238.htm on 22 March 2007.
} 
Mukhamed Tsikanov of the Economic Development and Trade Ministry indicated that there was a risk that Russia would not ratify because 'we don't have the economic stimulus, the economic interest in the Kyoto Protocol.' He did add that, for the moment, the plan in Moscow was still to ratify. By March 2003, this had still not occurred, prompting a visit by EC Environment Commissioner Margot Wallström and the Greek and Italian Environment Ministers to encourage Russia to follow through on its pledges. 'The world is waiting for Russia to demonstrate that it is ready and willing to become a major player in the multilateral efforts to combat climate change,' Ms Wallström stated ahead of her visit to Moscow. ${ }^{5}$

Between 29 September and 3 October 2003, the World Conference on Climate Change took place in Moscow. It was intended to be the first meeting of the parties to the Kyoto Protocol, but since Russia still had not ratified, this was not possible. President Putin's opening speech made clear that no exact date was set for Russian ratification. 'Russia is being actively called on to ratify the Kyoto protocol as soon as possible. I am certain that these appeals will also be heard many times at your meeting. I want to say that the Government of the Russian Federation is carefully examining and studying this issue, studying the entire range of complex problems connected with this', Putin said. 'A decision will be made after this work is finished. And, of course, it will be made in accordance with the national interests of the Russian Federation.' Joke Waller-Hunter, the executive secretary of the UNFCCC, was frank in expressing her disappointment. 'We had hoped that [President Putin] would have been somewhat more specific on the date when he would expect the Russian ratification to take place,' she said. 'Last year in Johannesburg, the [Russian] prime minister announced Russia would ratify the Kyoto Protocol in the nearest future, and we had hoped the nearest future had come today and that we would have a clear signal. ${ }^{6}$

The Conference itself definitely examined the issue of climate change and a very wide range of problems linked to it, but consensus on the benefits of Russia's ratification of the Kyoto Protocol was not reached. The opponents of Kyoto brought forward fierce arguments. Andrei Illarionov, economic adviser to President Putin, warned for instance that 'the Kyoto Protocol will stymie economic growth; it will doom Russia to poverty, weakness and backwardness', claiming that each percentage point of GDP growth is accompanied by a 2 per cent growth in $\mathrm{CO}_{2}$ emissions. ${ }^{7} \mathrm{He}$ also claimed that the EU legislation would stand in the way of buying any emission credits from Russia. ${ }^{8}$ Later on, Illarionov even went as far as comparing the Kyoto Protocol regime to Auschwitz. ${ }^{9}$

In all likelihood, the extremely negative stance towards Kyoto was part of a strategy to gain concessions from the EC in negotiations on Russia's WTO accession, as Commissioner Verheugen explained in a hearing in German Parliament. ${ }^{10}$ At the EU-Russia summit on 21

\footnotetext{
${ }_{6}^{5}$ Press release IP/03/322, Brussels, 5 March 2003.

6 <http://unfccc.int/press/stat2003/stat_290903.pdf>.

7 <http://www.rusnet.nl/news/2003/10/07/print/commentary_01_5423.shtml>.

${ }^{8}$ M. Ebell, Illarionov explains Russian position on Kyoto Protocol in Washington, Competitive Enterprise Institute, 13 February 20054. <http://www.cei.org/gencom/014,03867.cfm>

9 'The Kyoto Protocol is a death pact (...) because its main aim is to strangle economic growth and economic activity in countries that accept the protocol's requirements. At first we wanted to call this agreement a kind of international Gosplan, but then we realized Gosplan was much more humane and so we ought to call the Kyoto Protocol an international gulag. In the gulag, though, you got the same ration daily and it didn't get smaller day by day. In the end we had to call the Kyoto Protocol an international Auschwitz.' Illarionov likens Kyoto to Auschwitz, Moscow Times 15 April 2004. In an interview by Jeremy Paxman of the BBC, Illarionov on 18 May 2004 added: "We have received no single argument in favour of this document except political pressure. No link has been established between carbon dioxide emissions and climate change. No other objective facts have been presented in recent time. The IPCC's reports in 1990 and 1995 show it clearly." and "We are close to a consensus that the Kyoto Protocol does huge economic, political, social, and ecological damage to the Russian Federation." ${ }^{10}$ Deutscher Bundestag, Protokoll der 40. Sitzung des Ausschusses für die Angelegenheiten der Europäischen Union, 28 January 2004. Verheugen explained: „Tatsächlich gebe es Hinweise, dass Russland eine politische
} 
May 2004, President Putin announced that "[t]he European Union has made some concessions on some points during the negotiations on the WTO. This will inevitably have an impact on our positive attitude to the Kyoto process. We will speed up Russia's movement towards ratifying the Kyoto Protocol." Indeed, President Putin decided in favour of the Protocol in September 2004, along with the Russian cabinet. As anticipated after this, ratification by the State Duma (22 October 2004) and Federation Council (lower and upper house of parliament) did not encounter any obstacles. ${ }^{11}$ On 4 November 2004 the Protocol was approved by President Putin and Russia officially notified the United Nations of its ratification on 18 November 2004. In Russia itself, the ratification of the Kyoto Protocol was described as a necessity in exchange for the EC's support to the Russia's accession to the WTO. ${ }^{12}$ Ninety days after Russia's ratification the Kyoto Protocol entered into force on 16 February 2005.

\section{Russia's obligations and prospects under the KP}

The 1997 Kyoto Protocol takes 1990 levels of emissions as its basis. On the average, the developed (Annex I) countries to the KP have agreed to ensure a cut in greenhouse-gas emissions of at least 5\% from 1990 levels in the commitment period 2008-2012. Individual country targets range between $-8 \%$ and $+10 \%$. Russia has been allowed to return its enissions to its 1990 levels. Since 1990, the economies of most countries in the former Soviet Union have collapsed, as have their greenhouse gas emissions. This also holds true for Russia. In 1999, according to Russia's own 2002 inventory report to the UNFCCC, its emissions were 38\% below 1990 levels. In its 2006 inventory report, Russia indicated that although its CO2 emissions grew 11\% between 1999 and 2004, they were still 30\% below the 1990 levels. Although Russia's economy is expected to continue growing, the country does not foresee any problems in meeting its quantitative targets under the Kyoto Protocol for the 2008-2012 commitment period. ${ }^{13}$ In this respect, it is important to underline how far Illarionov was beside the truth when proclaiming that each percentage point of Russia's GDP growth would be accompanied by $2 \%$ growth in $\mathrm{CO} 2$ emissions. In reality, Russia's recovering economy shows that GDP growth with 30\% from 1998 to 2003 was not accompanied by $60 \%$ growth in $\mathrm{CO} 2$ emissions, but rather by a rate well below the GDP growth rate. ${ }^{14}$ This partial decoupling of GDP and carbon emissions since 1998 shows that energy efficiency in Russia is increasing, in line with the Russian Energy Strategy. ${ }^{15}$

\footnotetext{
Verbindung zwischen dem Abschluss der WTO-Beitrittsverhandlungen und der Ratifizierung des KyotoProtokolls herstellen wolle. Russland sehe darin weniger ein formelles Junktim als eine politische Paketlösung. Es scheine eine Herabstufung der Anforderungen an einen russischen WTO Beitritt durch eine Ratifizierung des Kyoto-Protokolls herbeiführen zu wollen." ("Indeed there are signs that Russia would like to create a political link between the conclusion of the WTO-accession negotiations and the ratification of the Kyoto Protocol. Russia regards this not so much as a formal, legal link but rather as a political package. It seems to be striving for a lowering of the conditions to a Russian WTO accession by ratification of the Kyoto Protocol.")

${ }^{11}$ The Duma voted 334 in favour of ratification, with 73 against and two abstentions.

12 "Russia forced to ratify Kyoto Protocol to become WTO member", Pravda, 2004-10-26. Retrieved on 200611-03. Whether one follows the EU or the Russian view on the reasons for ratification, it definitely is misleading to say that "Moscow offered prompt and unambiguous support to relevant European polices, easily ratifying the Kyoto Protocol” (B. Kaimakov, G8 summit promises nothing sensational, RIA Novosti, 2007-06-01. Retrieved on 2007-06-03.

${ }^{13}$ Fourth National Communication to UNFCCC and Progress Report submitted to UNFCCC on 13 February 2007.

${ }^{14}$ Institute of Energy Investigation of the Russian Academy of Sciences, Moscow, as cited in A. Korppoo, J. Karas and M. Grubb, Russia and the Kyoto Protocol, Opportunities and Challenges, Chatham House, 2006 at p. 25.

${ }^{15}$ http://www.rg.ru/2003/10/07/energetika.html . A Summary of the Energy Strategy of Russia for the Period of up to 2020, Ministry of Energy of the Russian Federation, Moscow, March 2003 is available at
} 
The latest forecast of Russia is that its CO2 emissions will still be some $25 \%$ below the 1990 levels by the end of 2012, in spite of further economic growth. ${ }^{16}$ This means that in all probability, Russia will have no problems in meeting its quantitative obligations under the Kyoto Protocol.

As for the post-2012 period, for which new obligations are still to be agreed upon, Russian forescasts predict that by the year 2020, CO2 emissions will still be 10 to $20 \%$ below 1990 levels. $^{17}$

An interesting point that was made in favour of a vigorous Russian energy-efficiency policy is the potential for energy exports. Russia's economic growth over the last years was to a considerable extend due to its oil and gas export. One commentator, Igor Bashmakov of CENEf (Centre for Energy Efficiency), even claims that if Russia would double its GDP (as is the goal set by President Putin) without improvements to its energy intensity levels, it would lose its capacity to export oil and gas already by the year $2010 .{ }^{18}$ In other words: if Russia wants to keep up its economic growth, this will depend on energy exports and these are only possible if energy-efficiency increases.

Whether or not Russia will be able to benefit from the Kyoto Protocol is doubted by some, ${ }^{19}$ but most agree that joining Kyoto offers valuable options for Russia, ${ }^{20}$ notably because its industry and electricity production suffer from major energy inefficiencies that could be dealt with via Joint Implementation projects. There is a large potential for improving energy efficiency in Russia, ${ }^{21}$ with energy use per unit of GDP being much greater than in the EU. ${ }^{22}$ Besides JI, to which we will return below, another option under the KP is the selling of assigned amounts units (AAUs). The KP enables countries like Russia with a surplus to sell parts of this surplus to other Annex 1 Parties. These unused assigned amounts are often referred to as 'hot air' because purchases would not yield environmental benefits. For Russia, however, the surpluses are a result of the humiliating economic decline and restructuring process, and benefits from sales of these surpluses are probably regarded more as compensation than as a 'windfall'. ${ }^{23}$ Anyway, Russia's significant surplus of emission quotas can be sold to other countries with targets when international emissions trading starts. The amount of money that Russia could earn by selling emission credits under the Kyoto Protocol will depend on the total amount of quotas it decides to sell and the market price of such

http://ec.europa.eu/energy/russia/events/doc/2003 strategy 2020_en.pdf. The document sets out Russia's energy policy for the period up to 2020. It was approved on 23 May 2003 and confirmed by the government on 28 August 2003. The main goals of this Strategy are energy safety, energy effectiveness, budget effectiveness and ecological energy security.

${ }^{16}$ Progress Report submitted to UNFCCC on 13 February 2007, p. 12.

${ }^{17}$ Idem.

${ }^{18}$ Bashmakov, I. (2004), Russian GDP doubling, district heating and climate change mitigation, presentation at the UNFCCC Workshop Climate Change Mitigation: Vulnerability and Risk, Sustainable Development,

Opportunities and Solutions, 19 June 2004, Bonn, Germany. Accessed at http://www.cenef.ru/bulletin/Bonn.ppt on 15 May 2007.

${ }^{19}$ Notably by the already mentioned former presidential adviser A. Illarionov.

${ }^{20}$ See for instance Kommersant 22 January 2007 and A.S. Dagoumas, G.K. Papagiannis, P.S. Dokopoulos, An economic assessment of the Kyoto Protocol application, Energy Policy 34 (2006) 26-39.

${ }^{21} \mathrm{See}$ for instance http://ec.europa.eu/energy/russia/reference texts/doc/2006_10_energy_efficiency_en.pdf.

${ }^{22}$ Viktor Danilov-Danilyan, Russia, Kyoto Protocol and Climate Change, Novosti, 16 February 2007. In 2003, Russia's CO2 emissions per unit of GDP were 1.2, much higher than in the Eurozone countries with 0.3; the USA 0.6 and China 0.6. The units reflect CO2 emissions in kilograms per unit of 2000 GDP in purchasing power partity (PPP) terms, i.e. gross domestic product converted to international dollars using PPP rates. An international dollar has the same purchasing power over GDP as a U.S. dollar has in the United States. Source: Worldbank, Little Green Data Book 2007.

${ }^{23}$ See further A. Korppoo, J. Karas and M. Grubb, Russia and the Kyoto Protocol, Opportunities and Challenges, Chatham House, 2006 at p. 41 and Woerdman, E. (2005), 'Hot air trading under the Kyoto Protocol: an environmental problem or not?', European Environmental Law Review, 14(3), 71-77. 
quotas. Without the USA participating, demand and thus prices are probably going to be less than first anticipated. Potential buyers of emission credits from Russia are the Canada, Japan and the EU. Russia itself introduced the concept of Green Investment Scheme (GIS) at COP-6 in December 2000. With such a GIS in place, revenues from the sale of surplus allowances would be earmarked for environmentally related purposes. The idea was not worked out further pending the period in which Russia was dragging its feet in ratifying the KP, but could be revived to accommodate concerns about 'hot air' trading.

As already indicated above, Russia could also invite other countries with emission targets to carry out emission reductions projects in Russia from which emission credits could be sold. Such Joint Implementation (JI) projects would enable Russian industry, especially in the energy sector, to become more efficient and less pollution-intensive. The projects could also help industry and municipalities to modernise and acquire new technology, for example in the district heating sector. ${ }^{24}$ Before JI projects can start in Russia, a number of institutional requirements set out in the KP need to be met.

\section{The adoption of general implementation measures}

Countries that ratified the Kyoto Protocol must create institutional arrangements for implementation. In order to prepare for the first commitment period of the Kyoto Protocol (2008-2012), after its ratification in November 2004, Russia first of all adopted a National Action Plan on the Kyoto Protocol Implementation in March $2005 .^{25}$ The plan sets out the distribution of responsibilities among 15 Federal governmental bodies (Ministries and Agencies) with regard to the realization of the KP in Russia (by mentioning the lead body and those further involved) and a (overly optimistic) timepath by which further action is to be taken (for instance: adopting JI procedures by mid-2005). In May of the same year, an InterAgency Commission on the Kyoto Protocol was established (lead by dept. Minister A. Sharonov of MEDT). ${ }^{26}$ This Commission upgraded the aforementioned Action Plan in July and October 2005. The MEDT came out as the responsible ministry coordinating Russia's implementation of the Kyoto Protocol.

Issues that were dealt with since then include:

- A national system of emissions estimation (национальная система оценки выбросов парниковых газов) ex Art. № 5 Kyoto protocol; established by Government Decree (01.03.2006 № 278-p). ${ }^{27}$ Roshydromet (the Russian HydroMeteorological organisation) is responsible for carrying it out.

- A National Inventory of emissions and removals (национальный кадастр выбросов и абсорбции) ex Art. № 7 Kyoto protocol; established by Roshydromet Order (30.06.2006 No.

\footnotetext{
${ }^{24}$ Q\&A: The entry into force of the Kyoto Protocol, MEMO/04/245, Brussels, 22 October 2004.

${ }^{25}$ Комплексного плана действий по реализации Киотского протокола в Российской Федерации. Тһе National Action Plan was actually initiated by a government decision of 30 September 2004.

${ }^{26}$ Межведомственная комиссия по проблемам реализации Киотского протокола в Российской Федерации (MBK).

${ }^{27}$ Правительство Российской Федерации, Распоряжение от 01.03.2006 N 278-p [О создании российской системы оценки антропогенных выбросов из источников и абсорбции поглотителями парниковых газов, не регулируемых Монреальским протоколом по веществам, разрушающим озоновый слой]
} 
141). ${ }^{28}$ On the basis of this document the National Inventory Report on 1990-2004 emissions was made. ${ }^{29}$

- The Fourth National Communication under the UNFCCC (2006). ${ }^{30}$

- The Report on progress in implementation of the Kyoto protocol (prepared by Ministry of Economic Development and Trade). ${ }^{31}$

- The Report on fixed quantities. ${ }^{32}$

- Organization administrating the Russian register of $\mathrm{CO} 2$ - "Federal centre of geoecological systems"; Government decree of 15.12.2006 No. 1741- $\mathrm{p}^{33}$ on creation of an organizationadministrator of Russian cadastre of carbon emissions.

In many respects, the reporting by Russia up until the Third National Communication was judged to be insufficient and not in accordance with prescribed formats, although progress was visible over the years. Hopefully, the Fourth National Communication, and the National Inventory Report for that matter, will continue to be more precise than the previous reports.

\section{The Joined Implementation regime}

Where JI is concerned, two options are available for the Parties to the KP: Track 1 (full eligibility) and Track 2 (partial eligibility). Russia opted for the second way, which implies among other things that JI projects will need to be verified by an Accredited Independent Entity (AIE), accredited by the JI Supervisory Committee (JI SC). For quite some time, Russian projects had been seeking approval from the Russian administration. On 28 May 2007, the long awaited Decree on JI in Russia was finally adopted (2 years later than the Russian Action Plan had set out). ${ }^{34}$ The main points of this decree can be summarized as following:

- The Russian JI Coordinating Centre responsible of preparation of JI projects approval is based at the Ministry of Economic Development and Trade (MEDT);

- The list of projects chosen by the MEDT is sent to the Government where it is getting final approval in consultation with the Federal executive bodies (governing given activities);

- The Russian Government can dismiss approved projects for reasons such as missing deadlines in reporting to the Coordination Centre and discontinuation of the activities of a private entrepreneur.

\footnotetext{
28 «Об утверждении Порядка формирования и функционирования российской системы оценки антропогенных выбросов из источников и абсорбции поглотителями парниковых газов». Приказ Росгидромета от 30 июня 2006 г. N 141.

${ }^{29}$ On 8 January 2007 Russia presented to the UNFCCC secretariat its National Inventory Report for the period 1990-2004. Compared to the Fourth National Communication data, presented in October 2006, emissions of the base year 1990 according to the new inventarisation have increased at 576 million tonn of CO2-equivalent. The major reason for this data increase is a better access to information and use of more exact data of production levels in the energy sector. The information was presented by the Federal Service of state statistics to Roshydromet, which is responsible for emission inventarisation.

${ }^{30}$ As of 10.03.2007 available in Russian only.

31 Доклад об очевидном прогрессе по выполнению обязательств по Киотскому протоколу

(Минэкономразвития России), http://www.ncsf.ru/resources/materials/62.pdf, retrieved on 10 June 2007.

32 Доклад об установленном количестве (МПР России), not available in internet yet.

${ }_{33}$ Распоряжение Правительства РФ от 15 декабря 2006 г. N 1741-р о создании организацииадминистратора российского реестра углеродных единиц.

${ }^{34}$ Постановление от 28 мая 2007 г. N 332 O порядке утверждения и проверки хода реализации проектов, осуществляемых в соответствии со статьей 6 Киотского протокола к Рамочной конвенции ООН об изменении климата (Decree of 28 May 2007 N 332 on the regime of approval and control of the operation of projects, carried out in accordance with Article 6 of the Kyoto Protocol to the UNFCCC).
} 
Pursuing this decree, the Rules on approval and assessment of JI project realization No. 0796, were adopted on 30 May 2007.35 These include the following provisions:

- The deponent deposits a project concept, project documentation and project passport with the coordinating centre (the Ministry); The documents shall be prepared according to the templates available on the website of the coordinating centre and signed by the deponent;

- The concept is approved by the commission set up by the coordinating centre, which also chooses independent expert organizations using the criteria given in Art. 6 of the Kyoto Protocol. The final list of expert organizations shall be available on website of the coordinating centre;

- Foreign deponents shall deposit the documents in the language of the respective country, with notarized translation in Russian.

- It is possible to conclude an international agreement on JI project implementation with a foreign counterpart.

- Projects realization shall not take place before January 1, 2008 or after December 31, 2012;

- It takes 10 working days for the coordination centre to register the project concept deposition, 30 days for respective Federal body to work the concept out and give a positive or negative conclusion on it, and 10 working days for the Government to give the final approval to the list of JI projects.

- The JI projects realization is assessed by a designated body (differs according to project's implementation sector), which on certain grounds (wrong project implementation) can come up with suggestion to the coordination centre on project's termination.

- The reporting period on the project is one calendar year.

- The disputes related to project realization are settled by means of negotiations within 6 month; otherwise sides can go to court or arbitrary court in accordance with the legislation and international obligations of Russian Federation.

Not everything is ready yet for JI projects in Russia. The MEDT together with the Ministry of Foreign Affairs will by 1 September 2007 need to come up with the template of international agreement between the Government of Russian Federation and foreign governments on project realization. Futhermore, standards on project efficiency will need to be adopted for project approval. The MEDT could have these ready by the end of the summer of 2007. Also, the list of independent experts needs to be made available. Thus, it remains unclear when exactly JI projects can go ahead in Russia. Also, the decree and rules described above still leave several questions unanswered, notably which other organizations will be involved, and thus a clear and transparent approval system for JI projects is still lacking. Meanwhile, that the timeframe for JI projects becomes really urgent as the start of the first commitment period (1 January 2008) is approaching and finalization of the rules and guidelines with regard to JI procedures will probably take up the rest of the summer of 2007, at least. At any rate, the die is cast. As so often in Russia, chances are that somehow, things will work out.

\section{Concluding remarks}

\footnotetext{
35 Положение от 30 мая 2007 г.,N 0796 об утверждении и проверке хода реализации проектов, осуществляемых в соответствии со статьей 6 Киотского протокола к Рамочной конвенции ООН об изменении климата
} 
Russia took its time before ratifying the 1997 Kyoto Protocol. After doing so in November 2004, an intensive debate on the modalities of implementation started. In March 2005, a National Action Plan on the Kyoto Protocol Implementation was adopted, while in May of the same year an Inter-Agency Commission on the Kyoto Protocol was established. Only at the end of May 2007, the first legislation with regard to JI was adopted. This means that the country's first emission reduction projects could soon be submitted to the UNFCCC JI approval process. The UNFCCC Secretariat estimates that these first emission reduction projects in Russia could reduce emissions of greenhouse gases by more than 65 million tonnes of CO2-equivalent over the five years from 2008 - i.e. approximately the emissions of Sweden during one year. ${ }^{36}$ The Ministry of Economic Development and Trade will be taking the lead in assessing, controlling and implementing the JI projects.

Hopefully, the implementation of the Protocol will turn out to be profitable for Russia. That would certainly contribute to a more positive stance of the country to a post-2012 regime than the views that were being expressed so far.

For a start, at a large conference on Climate Change in St. Petersburg held at the end of May 2007, the only state official attending, Federation Council Speaker Sergej Mironov, claimed in his opening speech that global warming does not exist and that in fact, the world is getting cooler. At the same conference, a government energy adviser warned that the KP would threaten the independence of the Russian oil and gas industry. ${ }^{37}$ More importantly, at the G8 Summit of Heiligendamm at the start of June 2007, Russia - together with the USA - refused to agree on firm post-2012 commitments. Instead, Russia and the USA only accepted to "consider seriously" to join the other G8 group members in their efforts in combating climate change by cutting greenhouse gas emissions 50 percent by $2050 .{ }^{38}$ Getting Russia on board of a meaningful post-2012 regime will thus be among the many challenges awaiting the European Union and others. Hopefully, the lessons that can be learned from Russia's ratification process will be taken at heart.

\footnotetext{
${ }^{36}$ UNFCCC press release 1 June 2007, "Russia poised to make use of Kyoto Protocol mechanism".

${ }^{37}$ S. Shuster, Mironov claims world is getting cooler, The St. Petersburg Times, 29 May 2007. Reportedly, mr Mironov based this remarkable opinion on several obscure Russian studies and - much in the style of Illarionov at conferences personally attended by the authors - hurried out at the end of the session without offering those attending the chance to ask questions.

${ }^{38}$ G8 Summit 2007 (Heiligendamm), Summit Declaration 7 June 2007: “In setting a global goal for emissions reductions in the process we have agreed today involving all major emitters, we will consider seriously the decisions made by the European Union, Canada and Japan which include at least a halving of global emissions by 2050 . We commit to achieving these goals and invite the major emerging economies to join us in this endeavour." (p. 15/16)
} 